\title{
INFLUÊNCIA DE INTERLOCUTORES NA PRODUÇÃO LINGUÍSTICA DE UMA CRIANÇA CODA DURANTE A AQUISIÇÃO BILÍNGUE E BIMODAL
}

\author{
INTERLOCUTORS INFLUENCE IN THE LINGUISTIC PRODUCTION OF A CODA \\ BIMODAL BILINGUAL ACQUISITION
}

\author{
Bianca Sena Gomes ${ }^{62}$ \\ Ronice Muller de Quadros ${ }^{63}$
}

\begin{abstract}
RESUMO: Este artigo tem como principais objetivos analisar o desenvolvimento linguístico de uma criança coda, bilíngue e biomodal, denominada ficticiamente de Edu, em diferentes idades, dentro do período de aquisição da linguagem - 1 ano e 4 meses, e 3 anos e 8 meses - num contexto de exposição e interação da criança com interlocutores com diferente características linguísticas, ou seja, ouvintes, surdos, monolíngues e bilíngues. Também objetivou-se investigar se, como, e em qual grau tais interlocutores influenciaram diferentemente a produção em si de Edu durante seu desenvolvimento. A análise, cujo cerne se encontra baseado na pesquisa desenvolvida por Gomes (2018), leva à conclusão de que a criança não só foi sensível ao interlocutor com quem interagia no que tange à percepção de diferenças linguísticas, como também mostra que tal sensibilidade se reverberou em tal nível a fazer com que Edu produzisse em diferentes modalidades linguísticas, seja gesto-visual ou oral-auditivamente, a depender justamente de seu interlocutor.
\end{abstract}

Palavras-chave: Aquisição da linguagem; codas; bilíngues bimodais; língua de sinais; Libras.

\begin{abstract}
The main objective of this paper is to analyze the linguistic development of a coda, bilingual and biomodal child, fictionally named Edu, at different ages, during the language acquisition period - 1 year and 4 months, and 3 years and 8 months - in a context of exposure and interaction of the child with interlocutors with different linguistic characteristics - be they deaf/hearing, monolingual/bilingual - as well as to investigate if, how, and to what degree these interlocutors differently influenced Edu's own production during his development. The analysis, the core of which is based on the research conducted by Gomes (2018), leads to the conclusion that the child was not only sensitive to the interlocutor with whom he interacted regarding the perception of linguistic differences, but it also shows that such sensitivity reverberated at such a level that made Edu produce in different linguistic modalities, be it oral-auditory or visual-spatial, depending precisely on his interlocutor.
\end{abstract}

Keywords: Language acquisition; CODA; bimodal bilingualism; sign language; Libras.

\section{Introdução}

Este artigo visa analisar o desenvolvimento linguístico no período de aquisição da linguagem de uma criança Coda bilíngue e bimodal em Língua Portuguesa e Língua Brasileira de Sinais através da análise de sua interação com interlocutores adultos, sendo eles surdos ou ouvintes, monolíngues ou bilíngues, bem como analisar a influência desses interlocutores em tal desenvolvimento. Para essa finalidade é necessário à compreensão de como ocorre o processo de aquisição da linguagem por crianças Codas que têm contato com duas línguas, com modalidades distintas, durante a infância. Essa sessão teórica, sendo a primeira parte do artigo, portanto, está relacionada justamente a três aspectos, que visam essa compreensão, sendo eles: aquisição da linguagem, bilinguismo e Codas.

Existem várias abordagens que tentam entender a aquisição da linguagem. Uma delas é da Teoria Inatista, predeterminada, elaborada por Chomsky (1965), que considera que a aquisição da linguagem é um processo inato dos seres humanos. No entanto, essa teoria contraria uma outra: a

\footnotetext{
${ }^{62}$ Professora de linguística no curso de Letras Libras na Universidade Federal do Cariri. Doutoranda de Linguística na Ppglin/UFSC.

${ }^{63}$ Professora e pesquisadora da Universidade Federal de Santa Catarina-UFSC; Pesquisadora do CNPQ - PQ1C. Pósdoutora pela Gallaudet University e University of Connecticut/CNPQ e pós-doutora na Harvard University /CNPQ.
} 
Teoria do Aprendizado da Linguagem, de um viés Behaviorista (CHOMSKY, 2009). Esta faz uso do conceito da "tabula rasa", isto é, a criança nasce sem qualquer tipo de conhecimento prévio, sendo que a linguagem é construída por estímulo-resposta-reforço (CHOMSKY, 1965, 2009; QUADROS; FINGER, 2008).

A primeira parte do pressuposto da existência de uma Gramática Universal (GU), que se aplica em qualquer língua, independente da modalidade linguística. Para Chomsky $(1965,1986)$, os humanos possuem uma competência linguística capaz de explicar como é possível que crianças com poucas informações de uma dada língua, manifestem uma produção tão grande dela. Uma das principais propriedades da Gramática Universal é o uso criativo da linguagem, definido como "[...] um aspecto fundamental da essência humana, [sendo que] essa criatividade determina que o ser humano seja capaz de compreender e produzir sentenças jamais ouvidas antes” (QUADROS; FINGER, 2017, p. 42). A capacidade especificamente humana de expressar novos pensamentos e de entender expressões inteiramente novas de pensamento, em quadro, de uma "língua instituída”, uma língua que é um produto cultural sujeito a lei e princípios em parte exclusivos dela e em parte reflexos das propriedades gerais da mente (CHOMSKY, 2009, p. 35)

Essa capacidade linguística, ainda relacionada ao conceito de Gramática Universal, é uniforme, ou seja, ocorre em qualquer língua do mundo em crianças que estão adquirindo a linguagem, independente das distintas relações sociais dos contextos onde estão inseridas. Além disso, este conceito explicita que as crianças têm processos de aquisição similares, independentes até mesmo da modalidade linguística (QUADROS; FINGER, 2008). Deste modo, Chomsky (2009) explica a Teoria Inatista, sendo que os seres humanos já nascem com a capacidade de aquisição da linguagem, tendo assim uma abordagem dedutiva, ou seja, parte-se do pressuposto que todas as línguas se encaixam no modelo proposto por ela.

O autor divide a linguagem em duas formas: a primeira, a Linguagem-E, determinada por fatores externos, que não tem relação direta com a mente; e a segunda, a Linguagem-I, que seria o uso interno da mente, independente de outros elementos individuais referentes à natureza humana (CHOMSKY, 2009; QUADROS; FINGER, 2017). Seria, portanto, uma linguagem interiorizada relacionada, assim, aos "princípios sobre os quais repousa o conhecimento da linguagem” (CHOMSKY, 2009, p. 8).

Segundo Quadros e Finger (2017) no que diz relação à Linguagem-I, a gramática tem a função de auxiliar o desenvolvimento da linguagem em algumas vertentes: considerando a estrutura da sentença, sendo essa gramatical ou agramatical; descrevendo a aquisição da linguagem e; apresentando um modelo de competência linguística.

Chomsky $(1965,2009)$ também discorre sobre a Teoria de Princípios e Parâmetros existente na Gramática Universal, sendo desenvolvida nos estudos naturais, abordando os Princípios Rígidos e os Princípios Abertos, estes últimos também denominados de Parâmetros. Os primeiros dizem respeito ao padrão de toda e qualquer gramática linguística. Os últimos assumem que as línguas têm variações, mas essas são permitidas pela Gramática Universal (GU) e são modeladas de acordo com as informações de uma ou mais línguas, conforme a exposição às mesmas - o que se denomina input.

No que diz respeito aos Princípios Abertos, as crianças teriam somente que fixar os valores que a GU oferece usando o input recebido (AUGUSTO, 1995), levando em consideração a interação entre fatores ambientais e biológicos. Assim, "A interação entre fatores ambientais e biológicos explica o uso que a criança faz da linguagem, tanto em relação à sua compreensão como à sua produção da linguagem" (QUADROS; FINGER, 2017, p. 52).

O input é fundamental para a aquisição da linguagem e se dá a partir do contato do indivíduo com o ambiente, a partir da exposição a uma ou mais línguas que funcionam como um gatilho que a inicia (QUADROS; FINGER, 2017). Neste contexto, as autoras usam a metáfora de uma flor que "precisa de condições ambientais para desenvolver depois que nasce" (QUADROS; 
FINGER, 2008, p. 56), similarmente à criança que precisa de input linguístico em fase de aquisição. Exemplificando tal necessidade, Kail (2013) aborda a importância do input linguístico semântico e pragmático no início da produção lexical da criança, sendo que crianças com mais input de substantivos, como as crianças americanas, tem tendência à produção desses. Já as crianças japonesas possuem maior produção de verbos devido também ao input recebido.

Com base na teoria de Chomsky sobre padrões da linguagem e existência da GU, a aquisição da linguagem passa por estágios que independem da modalidade linguística, seja ela, Língua de Sinais ou Línguas Orais e relativamente em pouco tempo, a criança consegue adquirir uma ou mais línguas, sem a necessidade de um aprendizado para isso, ou seja, de maneira inata, de acordo com o input recebido por elas.

A pesquisa deste artigo está relacionada à aquisição de línguas por um tipo específico de pessoa bilíngue: os Codas (Childrens of deaf Adults) - ouvintes filhos de pais surdos (SKLIAR, 2000; EMMOREY, 2001; QUADROS, 2017). Os Codas considerados são bilíngues bimodais, ou seja, têm duas línguas em modalidades distintas: uma língua visuoespacial e uma língua oralauditiva (LILLO-MARTIN et al., 2016; QUADROS, 2017). No caso específico do Brasil, os Codas adquirem a Libras e a Língua Portuguesa.

Os Codas adquirem a língua de sinais, normalmente, em casa com os pais; já com o restante da sociedade, são falantes da língua local do país. Para descrever este cenário, os pesquisadores da área utilizam o termo heritage signer (idioma do lar) (LILLO-MARTIN et al, 2016, tradução nossa). No caso do Brasil, em uma família de pais surdos, a língua voltada para a sociedade fora do lar seria o Português e a língua usada no lar, a Língua Brasileira de Sinais - Libras.

No contexto brasileiro, poderia ser realizada uma comparação dos Codas com os povos indígenas e de imigração, constituindo ambos minorias linguísticas e têm uma cultura linguística voltada para os seus familiares e também moldada por eles. No entanto, como frequentemente o Brasil é reconhecido como um país monolíngue (CAVALCANTE, 1999), esses povos são submetidos ao aprendizado também do Português, o que realimenta o processo de homogeneização linguística. Alguns Codas, também, adquirem tanto a cultura ouvinte quanto a dos surdos: normalmente frequentam espaços da comunidade surda, como associações, onde se comunicam fluentemente, podendo até serem confundidos com pessoas surdas, fato que também ocorre quando estão na comunidade ouvinte, ou seja, esse grupo de Codas, que possuem esse contato linguístico e cultural ocupam o que Quadros (2017) refere como terceiro espaço, exatamente por transitarem entre estes diferentes espaços e línguas. Por outro lado, também há Codas que apresentam efeitos observados com outros falantes de língua de herança, ou seja, acabam deixando de usar a língua de sinais.

As crianças Codas adquirem a língua de sinais e a língua oral normalmente nas fases de aquisição, mas, comumente, a língua usada em casa é distinta da usada na comunidade. Quadros (2017) define língua primária como a língua mais usada no cotidiano da criança, podendo ser a língua de herança ou a língua social. Há a possibilidade de a criança ter acesso primeiramente à língua de herança, sendo esta a sua L1 (primeira língua) e, posteriormente, por exemplo na escola, a outra língua, sua L2 (segunda língua). Nesse caso, é possível que a primeira língua (L1) se torne a língua secundária com o tempo, devido ao maior contato linguístico da criança com a sua L2 (segunda língua), língua secundária, que passa a ser sua língua primária (QUADROS, 2017).

Já em relação à proficiência na L1 e na L2, pode haver uma grande variação na produção e compreensão linguística, dependendo do contexto vivenciado pela criança e da política linguística local. Outro fator que serve para a compreensão de como é a produção linguística do Coda é a perspectiva do significado do bilinguismo o qual existe uma variação considerável de alguns conceitos que englobam o ser bilíngue.

Existem diversas definições do bilinguismo. Grosjean (1996) define a pessoa bilíngue como aquela que usa duas ou mais línguas na sua vida cotidiana, independentemente do grau de 
fluência neles. $\mathrm{O}$ autor cita pessoas, tais quais os imigrantes - que talvez não saibam se comunicar fluentemente com a língua do país ao qual foram acolhidos - intérpretes, membros de minorias linguísticas, etc. Ele acrescenta que "na verdade, os bilíngues adquirem e usam suas línguas para diferentes propósitos, em diferentes domínios da vida, com pessoas diferentes" (GROSJEAN, 1996, p. 2).

Ao pensarmos em domínios, podemos considerar o conjunto de elementos empiricamente determinados como local (escola, casa, escritório), papéis de relacionamentos (afetivo, amizade, profissional, família), conjunto de tópicos (religião, trabalho, educação, esportes). (MARCELINO, 2009, p. 8)

Nessa concepção, o bilinguismo, portanto, é considerado como o uso de línguas dependentes de influências dos espaços sociais que ocupam, não tendo a necessidade de a pessoa bilíngue ter fluência em ambas as línguas de forma igualitária. Sendo assim, é comum encontrar bilíngues que não tenham, por exemplo, as três habilidades linguísticas que incluem compreensão e produção - leitura, escrita e fala - pois não necessitam de todas elas no seu cotidiano (GROSJEAN, 1996). Com o olhar neste mesmo tema, Oliveira (2001) afirma que o conceito bilíngue traz complexidade e geralmente é dependente da competência linguística do falante, mas declara a dificuldade de se expressar o bilinguismo em uma sociedade monolíngue. Ela afirma que não há a necessidade "de perfeito domínio de duas ou mais línguas, mas toda a situação que envolve o falar línguas, seja em que situação for” (OLIVEIRA, 2001, p. 86).

Marcelino (2009) classifica o bilinguismo em três diferentes categorias no que diz respeito à exposição a dois idiomas: (a) bilinguismo simultâneo, quando as pessoas crescem com dois idiomas de forma igualitária; (b) bilíngues consecutivos, quando elas frequentam escolas de línguas estrangeiras esporadicamente, sem um contato diário com ambas as línguas; (c) bilíngue consecutivo de infância, quando há o contato de ambas línguas diariamente no contexto escolar, sendo o idioma parte da grade curricular e também usado como língua de instrução nestas escolas, de modo que as crianças se comunicam neste ambiente com as duas línguas.

Segundo o autor, existem graus de fluências distintos entre as pessoas dessas três categorias, sendo as da primeira (bilinguismo simultâneo) aquelas com maior produtividade em termos de habilidades linguísticas, tanto em produção como em compreensão. Grosjean (1989) critica a ideia de uma avaliação do bilinguismo pela fluência linguística. $\mathrm{O}$ autor discorre sobre a dificuldade de encontrar um "bilíngue ideal”, cuja compreensão e a produção linguística nas duas línguas seriam igualitárias. Por essa concepção, os bilíngues "não-ideais" seriam considerados como "menos bilíngues" pelo desnivelamento na fluência. Nesse sentido, Chen Pichler et al. (2014) argumenta que controles iguais entre as línguas raramente acontecem e que não se deve comparar bilíngues com monolíngues, pois os desenvolvimentos linguísticos entre estes dois grupos são diferentes entre si, isto é, as pessoas bilíngues apresentam comportamentos únicos, como misturas de línguas, que faz com que uma possível comparação com monolíngues não faça sentido. Pelas pessoas bilíngues, por exemplo, é normal o uso de uma estrutura gramatical de uma língua na outra (como ASL e o inglês, no caso estudado), fato que, ao invés de ser visto como uma característica distinta do aprendizado bilíngue, se comparado com o monolíngue, é frequentemente julgado como uma desordem linguística. As autoras enfatizam a importância de os pais, professores e terapeutas estarem cientes destas diferenças para que não haja um julgamento equivocado do comportamento de uma pessoa bilíngue.

Outra ideia criticada (GROSJEAN, 1989; PICHLER et al., 2014) é a de que uma pessoa bilíngue seria a "soma de dois monolíngues", não considerando os bilíngues como pessoas independentes dos monolíngues, com características de aprendizado, culturais e históricas próprias, que influenciam na produção linguística. Chen Pichler et al. (2014) dialoga sobre o assunto argumentando que a aquisição dos bilíngues bimodais, como sujeitos Codas, também deveria ser considerada distinta não somente dos monolíngues, mas também dos bilíngues 
unimodais. Os bilíngues bimodais acessam línguas em diferentes modalidades, enquanto os bilíngues unimodais desenvolvem-se linguisticamente em apenas uma modalidade (normalmente a modalidade oral-auditiva). As autoras mencionam ser ainda difícil definir o que seria um desenvolvimento "normal" de uma criança bilíngue bimodal pelo fato de haver pouca pesquisa na área e também uma grande diversidade de perfis de crianças, que apresentam diferentes domínios das línguas, devido aos mais diversos níveis de input recebido em seus diferentes contextos familiares/escolares. As autoras pesquisaram sobre crianças bilíngues bimodais e como resultado perceberam que, mesmo com a gama de comportamentos e de domínio linguísticos, nenhuma criança participante dos estudos foi diagnosticada como tendo algum tipo de desordem no desenvolvimento linguístico, fato que levou as autoras a reforçar a necessidade de que especialistas de saúde tenham conhecimento desta grande variedade de comportamentos, para que se evite diagnósticos de problemas linguísticos equivocados.

Grosjean (1989) argumenta que até os testes linguísticos empregados aos monolíngues são adaptados aos bilíngues, sugerindo, portanto, a necessidade de mudança desse sistema. Essa visão de "soma de monolíngues" tende a dar a impressão que o contato entre as duas línguas é acidental e anormal, porque os bilíngues deveriam ser compostos por uma figura de dois monolíngues separados, como se os sistemas entre as línguas tivessem características autônomas e não se encontrassem (GROSJEAN, 1989). Sendo assim, a justificativa para alguma característica considerada "anormal" neste contexto, como a expressão das duas línguas juntas, trata-se de "interferências linguísticas", visto que as línguas eram consideradas separadas, ou seja, sem relações. $\mathrm{O}$ autor defende a ideia da existência de relações linguísticas, sendo que o motivo para tal não se trata de mero fato acidental, mas sim de um laço intrínseco no desenvolvimento de ambas línguas no ser bilíngue, destacando dois tipos: o primeiro denominado de "interferência estática", quando há traços permanentes de uma língua na produção da outra, como sotaques estrangeiros; e a "interferência dinâmica", não permanente, quando há o uso esporádico de uma palavra de uma língua na outra (GROSJEAN, 1989).

Grosjean (1989) e Pichler et al (2014) propõem avaliar o bilinguismo como um todo, incluindo a valorização de todas as relações de interações linguísticas, independente do grau de fluência que a pessoa bilíngue tem em ambas as línguas que conhece, e discorrem sobre a existência de uma identidade linguística completa dos bilíngues e da necessidade dessa valorização ser reconhecida por outros pesquisadores da área.

Os seres bilíngues, portanto, desenvolvem competências linguísticas em um sistema de combinações entre as línguas; característica exigida por suas necessidades e as do ambiente. Outra conclusão do autor é que as línguas se mantêm ativas, independente da produção (GROSJEAN, 1989). O autor propõe a teoria de que as pessoas bilíngues conseguem mudar de língua na comunicação com facilidade, mas não se afastar de um nível de competência comunicativa necessária no meio no qual estão inseridas. Essa habilidade de troca de línguas só não é completamente configurada no período de aquisição, já que, neste período, o conhecimento de ambas línguas ainda está se consolidando.

Grosjean (1989) defende a ideia de que os indivíduos bilíngues adquirem as competências linguísticas de acordo com a necessidade do meio, semelhantemente ao que ocorre com os monolíngues. Considerando que o sujeito bilíngue é exposto a duas línguas diferentes, a aquisição poderá ocorrer nessas duas línguas, ou seja, crianças com acesso ao input consistente em mais de uma língua podem se desenvolver bilíngues. A partir de uma experiência continuada, essas crianças podem crescer completamente fluentes em ambas as línguas, embora uma delas possa ser dominante (QUADROS et al, 2012; QUADROS, 2017).

Em relação ao output linguístico, Grosjean (2001) pesquisou sobre as mudanças linguísticas que ocorrem no ser bilíngue, de acordo com os perfis dos interlocutores interagentes. Sendo assim, os bilíngues mudam sua maneira de falar quando em contato com monolíngues e quando em contato com bilíngues. Um bilíngue, até mesmo em contato com interlocutores bilíngues, que 
tinham domínio distinto das línguas - por exemplo, quando um interlocutor bilíngue sabia ler e escrever em uma língua, mas não sabia falar e outro sabia ler, escrever e falar - alterava o seu modo de conversar, segundo a pesquisa. Grosjean (2001) considera importante esse modo bilíngue nas pesquisas sobre as produções linguísticas e enfatiza que o modo bilíngue é algo natural e espontâneo.

Uma pesquisa realizada por Chen Pichler et al. (2014) também mostra essa sensibilidade de crianças aos interlocutores envolvidos e discorre sobre a existência de fatores que contribuem para a escolha de línguas das crianças, como a língua dominante e a tolerância dos pais pelas misturas de línguas realizadas. No momento que os pais estão interagindo, por exemplo, eles podem fazer escolhas linguísticas para influenciar o uso de determinada língua pelas crianças.

Os bilíngues geralmente escolhem uma língua base em função de fatores como os participantes envolvidos, os interlocutores, a situação, o tema e o objetivo da interação (GROSJEAN, 1982). Mesmo depois de uma escolha inicial, pode ocorrer a troca ou interação desta língua com a outra, fenômeno conhecido como Alternância Linguística, o que será melhor explicitado

Navarro (2003) discute sobre a maneira do interlocutor interferir no processo de aquisição da linguagem. $\mathrm{O}$ autor pesquisou o par linguístico inglês-espanhol, especificamente sobre o uso de sujeitos com pronomes nas sentenças produzidas. Ele argumenta a relevância de considerar o tipo de input recebido pela criança para, posteriormente, avaliar o seu output (produção). Era necessário averiguar como era a produção das línguas dos pais, que estavam interagindo com as crianças, a fim de compreender as relações do output da criança com os pais interlocutores do discurso.

Em sua pesquisa, portanto, mapeou algumas características do output dos pais, fazendo os seguintes questionamentos: $\mathrm{O}$ input bilíngue recebido pelas crianças tem erros?; os pais conseguem manter a regra de um falar uma língua e o outro falar a outra, ou; naturalmente ocorre uma mistura quando eles se comunicam entre si?; como os pais se comunicam quando as crianças estão presentes na conversa? Como resultado, foi verificado que a criança bilíngue produzia mais sentenças com sujeito usando pronomes do que as crianças monolíngues. Comparando o input recebido dos pais, o resultado foi correspondente, podendo sugerir que essa produção foi influenciada pelos inputs deles. Já as crianças monolíngues produziram menos sentenças com o uso do sujeito com pronomes, equivalentemente, os pais dessas realizavam também o mesmo output. A pesquisa enfoca a relevância de considerar a produção do interlocutor quando se pesquisa a produção da criança bilíngue.

Tal influência também foi sugerida por Lillo-Martin et al (2014) quando afirma que “crianças bilíngues desenvolvem uma sensibilidade à língua utilizada por seus interlocutores desde muito cedo, refletindo no uso diferencial de cada língua pela criança dependendo de seu interlocutor" (LILLO-MARTIN et al, 2014, p. 153).

Várias outras pesquisas (EMMOREY et al., 2005; QUADROS e GOMES, 2013; KANTO et al., 2013; CHEN PICHLER, 2014; QUADROS et al., 2017; QUADROS, 2017) também notaram a sensibilidade das crianças em relação aos interlocutores. Nesse sentido, Grosjean (1989) explana que os bilíngues adotam um tipo de fala de acordo com os interlocutores, sejam eles bilíngues ou monolíngues, e mostra que a resposta a cada interlocutor pode ocorrer de maneira distinta, mesmo se estiverem em um mesmo ambiente.

Este artigo pretende demonstrar essas influências dos interlocutores sobre a produção linguística da criança Coda, por meio da categorias estabelecidas a partir das produções linguísticas tanto da criança como do adulto com o qual ela interage, como pode ser visualizado a seguir.

\section{Material e métodos}

\subsection{Caracterização do estudo realizado}


O estudo foi desenvolvido a partir de quatro sessões de filmagens de uma criança Coda, denominada Edu, divididas em dois períodos de aquisição, 1:04 (um ano e quatro meses) e 3:08 (três anos e oito meses). Essas idades são as fases do período inicial e final de aquisição da linguagem, nesse caso, bilíngue e bimodal. Os vídeos mostram a interação com interlocutores diferentes: os pais surdos, um amigo ouvinte não fluente em Libras, um amigo ouvinte bilíngue bimodal.

No período inicial da aquisição, houve duas filmagens com interlocutores diferentes interagindo com Edu (1:04): uma realizada com a mãe surda oralizada ${ }^{64}$, fluente em Libras e em Português; a outra com Carlos, ouvinte, também fluente em ambas as línguas. Na fase final da aquisição, foi analisado um vídeo no qual o interlocutor era o pai surdo, bilíngue, mas não oralizado (Edu, 3;08). O último vídeo, Edu na mesma idade, interagiu com a Lara, ouvinte, monolíngue em Português. Os interlocutores, portanto, agregam tanto pessoas ouvintes - fluentes ou não na língua de sinais - bem como pessoas surdas - oralizadas ou não. Os vídeos não demonstraram produção sonora dos participantes surdos, por isso, não houve cálculo em relação à produção oral-auditiva desses sujeitos.

O conteúdo das filmagens apresenta o interlocutor interagindo com Edu com brincadeiras do cotidiano da criança como: bonecos, carrinhos, jogos e livros, e a duração dessas é de aproximadamente quarenta e cinco minutos por vídeo. O programa ELAN (EUDICO - Linguistic Annotator) foi utilizado para a transcrição. O ELAN possibilita anotações em trilhas de maneira sincronizada, em vídeo para a língua de sinais, e em áudio para o Português.

\subsection{Banco de Dados}

Os dados compõem o corpus do projeto Bilíngue Bimodal e Binacional (BIBIBI), que pertence a Universidade Federal de Santa Catarina (UFSC). O projeto desenvolve pesquisas de aquisições em língua de sinais no escopo do Núcleo de Aquisição da Língua de Sinais (NALS) ${ }^{65}$. Os dados acessados são longitudinais ${ }^{66}$, baseados em sessões de filmagens de uma criança Coda, EDU, no período de aquisição da linguagem, que acontece entre 1 e 4 anos de idade. As sessões têm sempre alternância na língua alvo, Português e Libras, o registro de exposição e interação espontânea às duas línguas.

Os vídeos foram selecionados por dois critérios: (a) a idade de Edu, sendo que a aquisição da linguagem ocorre, normalmente, entre o nascimento até os 4 anos. As idades, portanto, foram 1:04 e 3:08. (b) As características distintas dos interlocutores interagentes com Edu nas filmagens, por serem surdos ou ouvintes; e também o status bilíngue foi considerado: ser bilíngue ou ser monolíngue.

\subsection{Transcrição dos dados}

A transcrição dos dados foi realizada utilizando-se o ELAN (Eudico Annotator disponível em https://tla.mpi.nl/tools/tla-tools/elan/). O sistema de anotação do ELAN tem sido utilizado em estudos com línguas de sinais por permitir anotações linguísticas associadas à vídeos. Foram usadas as trilhas já existentes do NALS para o estudo de bilíngues bimodais.

As trilhas básicas utilizadas foram as seguintes: Libras, Português e tradução para Edu e Libras, Português e tradução para os interlocutores.

\footnotetext{
${ }^{64}$ Oralizada: utiliza também do método oral para viés de comunicação

${ }^{65}$ Site do Núcleo de aquisição da linguagem de Língua de Sinais: http://nals.cce.ufsc.br/

${ }^{66}$ Dados longitudinais, sessões de filmagens coletadas durante anos com aproximadamente 50 minutos cada sessão. (QUADROS, 2010)
} 
A transcrição de Libras, tanto do interlocutor como de Edu, foi realizada em glosas (com letras maiúsculas), ou seja, cada sinal produzido pelos participantes era transformado em glosa para o Português. Para tal fim, houve a utilização do modelo de transcrição do projeto BIBIBI ${ }^{67}$. Vejam o exemplo a seguir:

\section{EDU: BOCA VERMELHO Mãe: VERMELHO}

A transcrição em Português foi desenvolvida por uma escrita contínua segmentada por sentenças ou palavras soltas de acordo com a produção dos participantes. Por exemplo

EDU: Está tudo arrumadinho!

Lara: Não está tudo arrumadinho?

A seguinte categorização da produção foi utilizada no processo de transcrição de Português:

a) Ação: produção de barulho de algum objeto ou animal;

b) Palavras Port: produção de palavras soltas em Português;

c) Sentenças Port: produção de sentenças em Português;

d) Vocalizações: algum tipo de vocalização prosódico;

e) Fatores não reconhecidos: produções não reconhecidas na transcrição eram transcritas como "xxx".

Em paralelo, a categorização da produção utilizada no processo de transcrição de Libras foi a seguinte:

f) Apontação: produção de apontar para algum objeto, pessoa, lugar;

g) Descrição Visual: uso classificador/descrição imagética;

h) Gestos: uso de gestos e emblemas, geralmente, para imitar algo;

i) Palavra Sinal: uso de palavras da Libras;

j) Sentenças: uso de sentenças em Libras;

k) Fatores não reconhecidos: produção sem significado definido na transcrição era escrito "xxx".

As transcrições e as categorizações realizadas viabilizaram a análise dos dados.

\section{Análise dos dados}

Neste estudo, Edu interagiu com Carlos, ouvinte e bilíngue; e com sua mãe, surda e oralizada, no início do período de aquisição da linguagem, assim como interagiu com Lara, ouvinte e monolíngue; e o pai, surdo não oralizado, no final deste período. A produção linguística, tanto no que tange à criança, quanto aos interlocutores, foi dividida em duas modalidades - oralauditiva e gesto-visual - para viabilizar a análise da influência dos interlocutores na produção de Edu.

Para cada modalidade, a produção linguística dos envolvidos foi dividida e quantificada em diferentes categorias, como detalhado na seção anterior. Além disso, calculou-se o MLU ${ }^{68}$ (Extensão Média do Enunciado) da produção dos envolvidos em cada episódio investigado.

\footnotetext{
${ }^{67}$ Disponível em:

https://repositorio.ufsc.br/bitstream/handle/123456789/169881/2015\%202905\%20MANUAL_CORPUS\%20tran scric\%CC\%A7a\%CC\%83o.pdf?sequence $=1 \&$ isAllowed $=$.

${ }^{68} \mathrm{O}$ MLU calcula a extensão média de palavras produzidas por enunciado.
} 
A seguir será demostrado, o resultado deste levantamento estatístico dos dados analisados em todos os casos de comunicação de Edu com seus interlocutores, sejam tais casos em Libras ou Português.

\subsection{Análise da produção de Edu no início da aquisição da linguagem (1;04)}

$\mathrm{Na}$ idade de 1;04, Edu interagiu com Carlos e a Mãe. Abaixo, seguem análises destes contatos linguísticos.

\subsubsection{Análise da produção oral-auditiva (Português): Edu (1;04) e Carlos}

O primeiro vídeo analisado foi de Edu $(1 ; 04)$ com o interlocutor Carlos: ouvinte, bilíngue em Português e Libras. Este vídeo possui aproximadamente 45 minutos. Nele, os envolvidos se comunicaram por Libras e Português, sendo que a última língua, foi a língua-alvo da sessão. Abaixo a análise relativa à produção em Português dos participantes.

Edu e Carlos tiveram a produção de todas as categorias orais-auditivas em Português. Como pode ser visualizado no gráfico 1, a produção oral-auditiva de Edu, apresenta uma alta produtividade de "Palavras Port" (109), e uma produção reduzida de "Sentenças Port" (9).

Gráfico 1. Comparação entre produção oral-auditiva (Português) de Carlos e Edu (1;04)

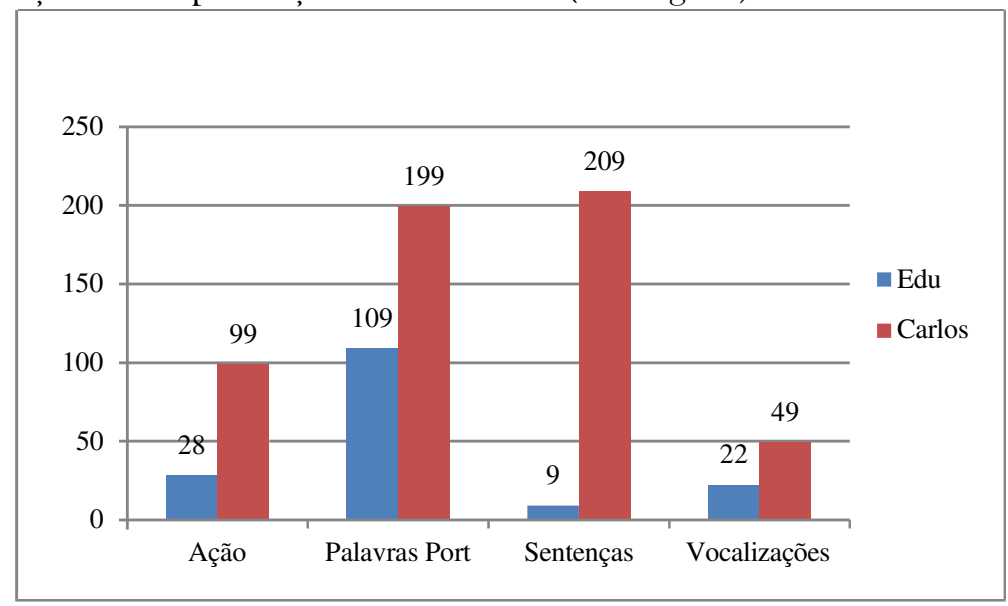

Fonte: Gomes (2018:83).

Esse resultado é esperado, uma vez que Edu está na fase inicial de aquisição e ainda não tem a maturidade linguística necessária para constituir "Sentenças" em uma proporção maior que "Palavras Port". Neste sentido, é interessante ressaltar que o próprio fato de que há produção de "Sentenças" nesta idade mostra o desenvolvimento antecipado no estágio de aquisição (QUADROS; FINGER, 2017).

Como esperado, Carlos, por ser adulto e já possuir a aquisição linguística completa, ou seja, pelo fato de ter um desenvolvimento linguístico mais avançado que o de Edu, demonstra capacidade maior de produção de todas categorias que a criança, especialmente no que diz respeito às "Sentenças", já que produzir esta categoria é naturalmente mais difícil do a categoria "Palavras Port”, (KAIL, 2013).

Corroborando esta percepção, a Tabela 1 mostra que o MLU relativo à produção em Português de Edu - 2,2 - é menor que o de Carlos - 3,0 - 
Tabela 1 - Produção do MLU em Português por indivíduo - Edu (1;04)

\begin{tabular}{cc}
\hline Pessoa & MLU \\
\hline Edu & 2,2 \\
Carlos & 3,0
\end{tabular}

Fonte: Gomes (2018:84).

Também percebe-se que Carlos está adequando a sua produção ao nível de entendimento da criança, pois suas sentenças são relativamente curtas (MLU de 3,0), considerando-se o padrão adulto (MLU entre 3,0 e 7,0).

\subsubsection{Análise da produção gesto-visual (Libras): Edu (1;04) e Carlos}

O mesmo vídeo da seção anterior foi analisado também quanto à produção em Libras entre os participantes. Sobre a produção nesta modalidade, conforme as categorizações predefinidas, segue análise e observações abaixo.

Edu e Carlos tiveram produção em Libras, como sintetizado no gráfico 2. O uso de "Setenças" por Carlos já era esperado, já que o adulto tem fluência linguística também nesta língua, no entanto, percebe-se que a produção de "Setenças" não foi elevada - somente 20 - já que a língua alvo da sessão era o Português. Chama atenção o fato de que, ainda neste contexto de maior foco no Português, Edu, mesmo no início da idade de aquisição de linguagem, também foi apto a produzir "Setenças" em Libras, categoria perceptivelmetne mais complexa.

Gráfico 2. Comparação entre produção visual-espacial (Libras) de Carlos e Edu (1;04)

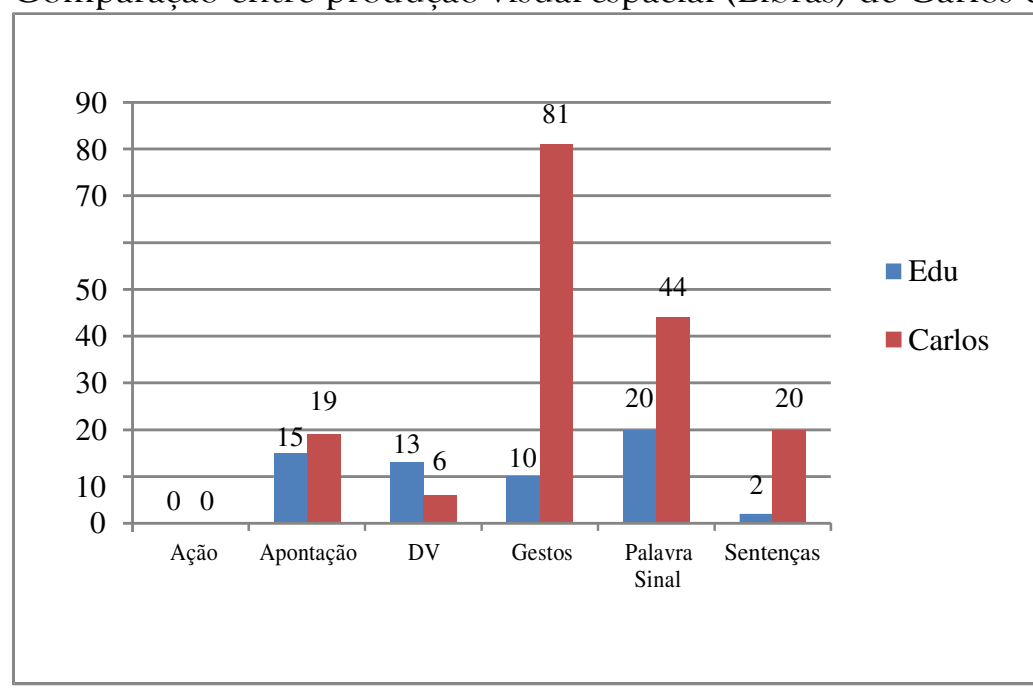

Fonte: Gomes (2018:86).

Observou-se de modo geral que a maior produção de Carlos foi de "Gestos". Talvez esse fato possa estar relacionado ao fenômeno de "Co-specch gesture": produção gestual associadas à fala em qualquer língua, como, neste caso, ao Português (KANTO, 2017). Além disso, pode-se verificar que as categorias "Apontação" e "Palavra Sinal" de ambos participantes se mostram correlacionadas, o que contrasta com o ocorrido com a categoria "DV".

Esta diferença pode estar relacionada com o fato de que Edu está crescendo em um ambiente bilíngue bimodal, adquirindo ambas línguas. Os aspectos visuais e culturais destas línguas, como "DV"s, acabam se manifestando nas interações com interlocutores de ambas modalidades. Carlos, por outro lado, não teve uma educação bilíngue. Ele tem a Libras como sua segunda língua, faltando-lhe, talvez, alguns aspectos culturais da educação bilingue que já são mais observados na produção de Edu. 
A tabela 2 mostra o MLU em Libras dos sujeitos analisados.

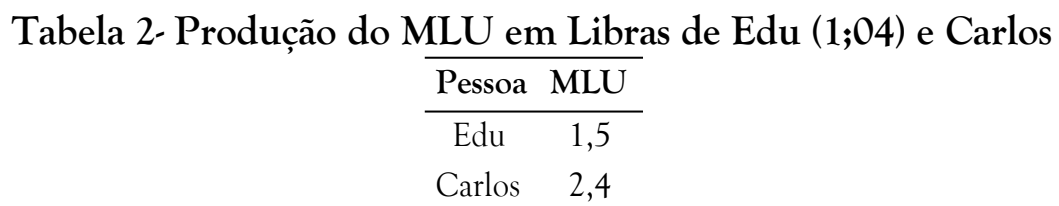

Fonte: Gomes (2018:86).

Como é possível perceber na tabela 2, comparando-a à tabela 1, o MLU em Libras, de ambos os participantes, é menor que o MLU em Português. Cogita-se que esta distinção teria justificativas diferentes para cada interlocutor: enquanto o MLU maior em Português de Edu pode indicar uma preferência pelo uso desta língua devido à influência de seu interlocutor; Carlos, por outro lado, apresenta maior MLU nesta língua não só por tê-la ele próprio como L1, como porque esta era a língua alvo da sessão.

\subsubsection{Análise da produção oral-auditiva: Edu (1;04) interagindo com a mãe}

O segundo vídeo analisado foi de Edu $(1 ; 04)$ com a sua mãe: surda, bilíngue em Português e Libras, e oralizada. Este vídeo também possui aproximadamente 45 minutos. Nele, a mãe se comunicou naturalmente, ou seja, sem intervenção dos pesquisadores, somente em Libras, havendo esta sido, portanto, a língua-alvo da sessão. Devido a isso, a análise da produção de Português dela não foi realizada. Abaixo a análise relativa à produção em Libras de ambos participantes, e de Português de Edu.

Edu utilizou todas categorias orais-auditivas em Português, distribuídas da seguinte maneira: Ação (9), Palavras Port (96), Sentenças (18) e Vocalizações (7). Em termos absolutos, a maior produção foi da categoria "Palavras Port" (96) e a menor de "Oralizações" (7). Comparativamente, pode ser notado que as oralizações com Carlos foram mais frequentes do que com a mãe, podendo isso sugerir uma influência do interlocutor na produção da criança, já que a mãe de Edu não produziu Português durante esta filmagem.

Edu contabilizou 2,8 de MLU em Português, um resultado elevado para a aquisição da linguagem, se analisado conforme os valores desenvolvidos por Brown (1994).

É interessante ressaltar que o valor de MLU de Edu interagindo com a mãe $(2,8)$ foi maior do que aquele com Carlos $(1,5)$. Apesar da influência de um interlocutor ouvinte resultar numa expectativa de produção mais complexa - medida por um maior MLU - em Português, pode-se notar que a influência trazida pela proximidade afetiva da mãe como interlocutora somada ao fato de a consciência por parte de Edu de que a mãe era oralizada e, portanto, compreendia a sua fala, produziram um efeito de produção de maior complexidade, já que Edu conversava mais aberta- e fluentemente com a mãe, assim como previsto no estudos de Grosjean (2001).

\subsubsection{Análise da produção gesto-visual (Libras) de Edu (1;04) com a mãe}

A seguir será analisada a produção gesto-visual (Libras) de Edu no mesmo vídeo de interação com a mãe. A caracterização desta produção foi distribuída segundo o gráfico abaixo.

Como pode ser visto, Edu não produziu "Ação", "DV" e "Sentenças". A maior produção da mãe foi de "Sentenças", e a menor de "DV". Uma relevante observação é que, apesar de Edu não produzir as mesmas categorias que a mãe, todas as que ele produziu, a mãe também o fez, demonstrando a influência do interlocutor. 
Gráfico 3. Comparação entre a produção gesto-visual (Libras) de Edu (1;04) e da Mãe

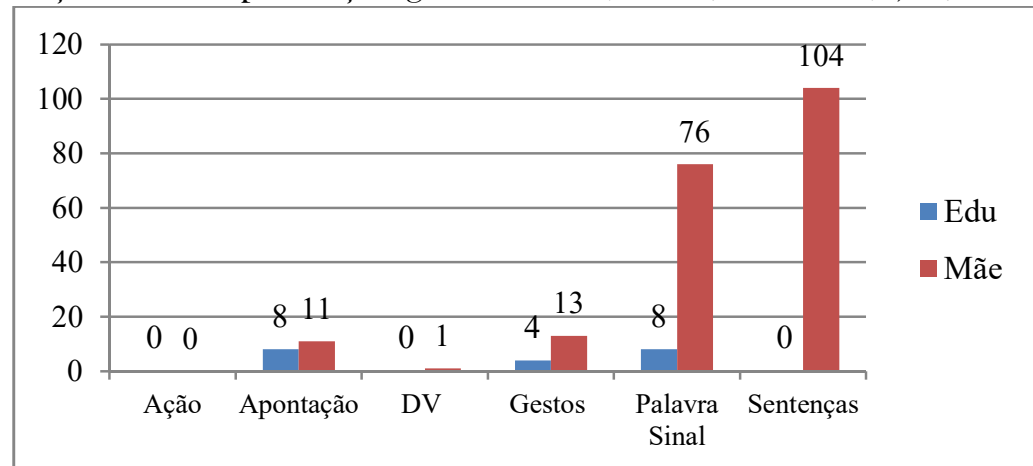

Fonte: Gomes (2018:94)

O MLU da mãe foi de $(3,2)$. Edu não produziu sentenças, por isso houve uma impossibilidade de calcular seu MLU.

\subsection{Análise da produção de Edu no final da aquisição da linguagem (3;08)}

Abaixo seguem as sessões analisadas de Edu $(3 ; 08)$ interagindo com Lara e com o pai. A primeira é monolíngue em Português, já o pai é surdo, tem Libras como L1 e é não oralizado.

\subsubsection{Análise da produção oral-auditiva (Português): Edu (3;04) com Lara}

O primeiro vídeo nesta idade de Edu (3;04) mostra a interação desta criança com Lara. Edu produziu em Libras e Português, enquanto Lara produziu somente em Português, já que ela é monolíngue nesta língua. Esta seção é dedicada à análise do vídeo no que tange à produção de Português entre os participantes.

O gráfico 4 demonstra a categorização da produção dos participantes nesta língua. É possível notar que Edu produziu, em termos absolutos, maior output de "Sentenças" (451) e menor de "Ação" (11). Esse resultado era esperado, já que Edu está na fase final de aquisição da linguagem, onde a criança produz uma grande quantidade de sentenças (QUADROS; FINGER, 2017). As outras produções foram de "Vocalizações" (32) e "Palavras Port" (231).

Outra observação é que a criança continuou produzindo todas as categorias orais-auditivas estabelecidas na pesquisa, análogo ao que aconteceu quando ela tinha 1 ano e 4 meses

A figura 4 mostra que Lara produziu somente as categorias de "Sentenças" (576) e "Palavras Port” (146), sendo a produção da primeira composta por sentenças complexas e simples. A primeira língua da Lara é o Português, sendo assim, é normal essa alta produção sintática.

Gráfico 4. Comparação da produção oral-auditiva (Português) da Lara e de Edu $(3 ; 08)$

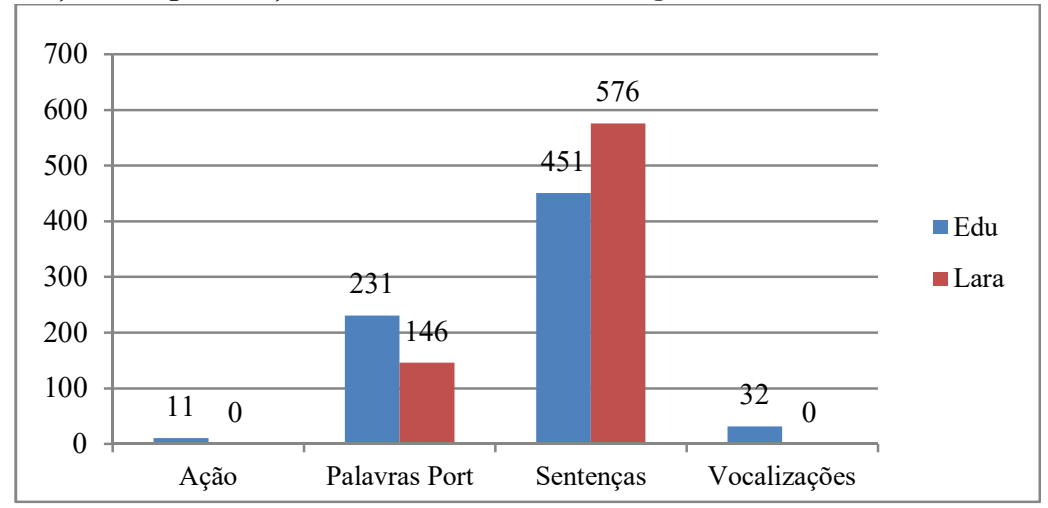

Fonte: Gomes (2018: 101). 
Edu produziu uma grande escala de "Sentenças", mas em quantidade inferior que a Lara. Já a produção de "Palavras Port" por Edu foi maior do que aquela por Lara, o que também é considerado normal, já que a capacidade da criança de ordenar tais palavras em sentenças ainda está em desenvolvimento. Outra averiguação é que Lara não produziu todas as categorias, já Edu continuou produzindo, em menor escala, todas elas, diferente dos outros vídeos, nos quais Edu só produzia as categorias produzidas pelo interlocutor interagente.

A tabela abaixo mostra o MLU relativo à produção de Edu $(2,3)$ e da Lara $(4,0)$.

Tabela 3 - Produção do MLU por indivíduo (Edu com 3;08)

\begin{tabular}{cc}
\hline Pessoa & MLU \\
\hline Lara & 4,0 \\
\hline Edu & 2,3 \\
Fonte:Gomes $(2018: 102)$
\end{tabular}

O MLU da Lara foi praticamente o dobro de Edu, como já esperado, pois Edu está no final da aquisição da linguagem, mas ainda não completou o processo.

\subsubsection{Análise da produção gesto-visual: Edu (Libras) com Lara}

Esta seção dedica-se à análise da produção gesto-visual em relação ao mesmo vídeo da interação entre Edu e Lara. Como Lara é monolíngue em Português, não houve categorização da produção nesta modalidade de Laura, mas somente de Edu.

Edu produziu quatro categorias, sendo elas: "Apontação" (5), "DV” (1), "Gestos” (8), e "Palavras Sinal" (11). É interessante ressaltar que, mesmo Edu estando interagindo com uma pessoa ouvinte e monolíngue em o Português, existe produção de língua de sinais, em pequena quantidade, comprovando a existência da aquisição de ambas as línguas. Lara também produziu Palavras Sinais, mas somente três, mesmo sendo monolíngue. Emmorey et al. (2005) já notou esse tipo de acontecimento em monolíngues, que produziam de maneira inconsciente, pelo conhecimento prévio de alguns sinais, fato que não os tornava classificáveis como bilíngues.

O cálculo de MLU dos participantes não foi realizado pelo fato de ambos não terem produzido sentenças.

\subsubsection{Análises gesto-visual (Libras): Edu (3;04) com o pai}

O segundo vídeo nesta idade de Edu (3;04) mostra a interação desta criança com o pai que, diferentemente da mãe, não é oralizado. Edu produziu em Libras e Português, enquanto o pai produziu somente em Libras. Esta seção é dedicada à análise do vídeo no que tange à produção de Libras entre os participantes.

O gráfico 5 demonstra a produção de Edu e de seu pai. Nota-se que a produção de Edu abrangeu todas as categorias gestuais-visuais. Uma averiguação é que o pai também produziu as mesmas categorias que Edu, porém com uma maior proporção de "Sentenças" (262 do pai contra 34 de Edu), mostrando a natural maior fluência do pai. 


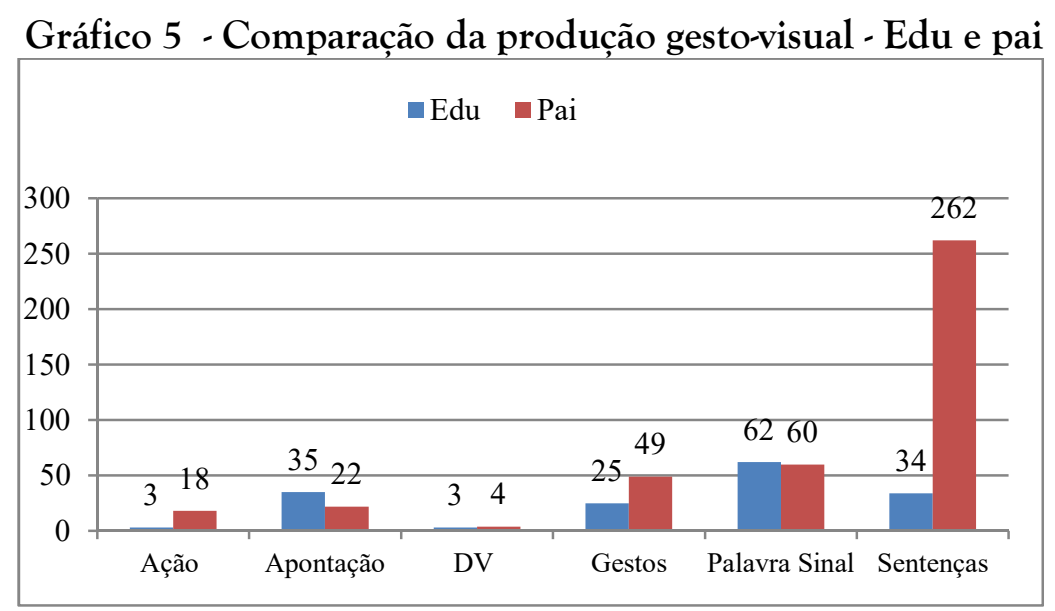

Fonte: Gomes (2018:108).

O MLU em Libras de Edu foi de 2,1, fazendo com que a criança se enquadre no terceiro estágio de aquisição da linguagem (BROWN, 1973). O MLU do pai nesta mesma língua foi de 3,2.

\begin{tabular}{cc}
\multicolumn{2}{c}{ Tabela 4- Produção do MLU - Edu e pai } \\
\hline Pessoa & MLU \\
\hline Edu & 2,1 \\
\hline Pai & 3,2
\end{tabular}

Fonte: Gomes (2018:109).

É importante notar que, comparativamente a todos outros interlocutores com quem Edu interagiu, e, tendo como base os gráficos de caracterização de produção e MLUs calculados, a sua produção de Português não só foi menor, com a sua produção de Libras foi maior, justamente quando ele interagia com o pai, que tem como característica distinta dos outros interlocutores não ser oralizado, constatação esta que, mais uma vez, sugere a influência do interlocutor na produção linguística da criança.

\section{Resultados e discussões}

A seguir, serão apresentados os resultados e discussões das análises dos dados explicitados nas seções anteriores. A primeira análise, será sobre Edu e interagindo com Carlos; a segunda, Edu interagindo com a mãe; a terceira, Edu interagindo com o Pai, e por último Edu interagindo com a Lara.

\subsection{Produção de Edu (1;04): Carlos e mãe}

Com Relação a Edu interagindo com o Carlos e com a mãe no início da aquisição da linguagem, tendo 1;04 notou-se as seguintes considerações:

A. O output de Edu em relação à produção gesto-visual e oral-auditiva, no início da aquisição da linguagem, pode se encaixar no "Período Linguístico da Aquisição da Linguagem, estágio de uma palavra ou de um sinal, que acontece, por volta, de um ano" (QUADROS E FINGER, 2017, p. 60). Nesse período, geralmente, a criança começa a produzir palavras/sinais que têm relação com o meio ambiente, principalmente substantivos e verbos. (KAIL, 2013; QUADROS; FINGER, 2017).

B. A produção de palavras/sinais de Edu foi relacionada ao ambiente em que o vídeo estava sendo filmado, sendo que algumas palavras em PORTUGUÊS produzidas, por exemplo, foram "mãe", "milho", "carrinho", itens que estavam presentes no vídeo. Similarmente, foi observado o 
mesmo fenômeno em Libras. Alguns exemplos seriam "DORMIR", "ELEFANTE" "HELICÓPTERO". As autoras Quadros; Finger (2017) também argumentam que existe o processo de superestensão nessa fase, processo através do qual a criança aplica o reconhecimento de uma característica de um dado ser/objeto a demais seres/objetos que compartilham esta mesma característica. Edu, por exemplo, produziu palavras em PORTUGUÊS como "auauu", "piupiu" com as quais poderia estar se referindo a diferentes animais, não necessariamente aqueles que produzem estes sons.. Os dados também mostraram que houve a produção de vocalizações que estão relacionadas mais com a concordância e discordância no discurso, não sendo necessária a presença de uma palavra ou sentença específica para isso (KAIL, 2013). Já as ações produzidas podem estar relacionadas com a presença de contações de histórias no vídeo e brinquedos, proporcionadas pelo interlocutor, para manter a interação com a criança de forma lúdica.

C. Antes mesmo do esperado, Edu começou com 1;04 a produção de sentenças em PORTUGUES e Libras, fato que geralmente ocorre por volta de dois anos de idade (QUADROS, 1997; KAIL, 2013; QUADROS; CRUZ, 2011, QUADROS; FINGER, 2017). Nesta idade, normalmente, a criança não produz elementos de ligação (QUADROS; FINGER, 2017), mas, no caso de Edu, eles foram produzidos em sentenças PORTUGUÊS como "É MEU".

D. Ainda antes do esperado, em Libras, Edu, nesta idade de 1;04, também produziu sentenças como "IX (apontar para interlocutor) SONO". Segundo Quadros e Cruz (2011), a criança surda, de maneira geral, começa a aquisição dos pontos no espaço incluindo os interlocutores para a segunda pessoa (VOCÊ) somente aos dois anos de idade.

E. O MLU de Edu de Libras e de Português mostrou que ele está inserido no primeiro estágio de aquisição, em ambas as línguas, número que, segundo Brown (1973), é esperado, neste período, estar na faixa de valores maior que 1 e menor que 2. O critério de Brown foi concebido para analisar o desenvolvimento de crianças monolíngues, no entanto, o resultado do MLU de Edu parece ser compativel com esta faixa de valores.

F. Pode-se perceber que com um ano e quatro meses de maneira geral, a produção de Edu, em relação à aquisição de ambas as línguas, ocorre equivalentemente à produção de uma criança monolíngue, em várias perspectivas, como sinais, palavras, sentenças, MLU. Tal fato também ocorreu na pesquisa de Petitto (2003), onde as crianças Codas tiveram produção semelhante às crianças monolíngues. Portanto, demonstrou a aquisição bilíngue de Edu tanto em relação à Libras como no Português.

\subsection{Sensibilidade de Edu (1;04): Carlos e mãe}

Em relação à sensibilidade de Edu para com o interlocutor com quem interagia no vídeo, foi possível realizar as seguintes observações: Carlos;

Edu produziu as mesmas categorias orais-auditivas e visuais espaciais que o interlocutor

Os dois (Carlos e Edu) usaram o Português como língua primária na sessão de filmagem;

A. Como esperado, a produção de Carlos foi maior em todas categorias analisadas, com exceção da quantidade de DVs, que foi mais que o dobro maior no caso de Edu. Isso pode se dever às características da aquisição natural de Edu por ser filho de pais surdos, onde há um input de língua de sinais diário pelos pais resultando em um output mais visual (QUADROS, 2017);

B. Carlos teve um maior output oral-auditivo comparando com o visual-espacial, fato que também ocorreu com Edu;

C. A produção de MLU de Carlos foi maior na modalidade oral-auditiva, fato que também ocorreu com Edu;

Esses resultados demonstram que existe uma relação entre a produção da criança Coda com seu interlocutor. Esta sensibilidade permite averiguar que a aquisição de crianças sofre influência 
das pessoas que estão ao seu redor e com quem interagem. No caso em questão, o fato de que foi possível traçar um paralelo da produção de Edu com Carlos, permite enxergar um fator de consequência entre estas produções a partir da exposição de Edu aos inputs de seu interlocutor, tanto nos tipos, quanto na quantidade e não somente em relação a fatores linguísticos como MLU, mas também às categorias orais-auditivas e gesto-visuais avaliadas.

Outras pesquisas já mostraram a sensibilidade de crianças Codas em relação ao interlocutor (GROSJEAN 1989; NAVARRO, 2003; PETITTO, 2003; QUADROS; GOMES, 2013; LILLOMARTIN et al., 2014; KANTO, 2017), mas o trabalho em questão tenta demonstrar de maneira mais detalhada essa influência através das observações oriundas do levantamento e tratamento estatístico classificatório dos dados transcritos.

Quanto à sensibilidade de Edu no que diz respeito à mãe, é possível estabelecer que, apesar da produção de Edu ter sido menor no que diz respeito à produção gesto-visual, ele conseguiu produzir elementos de todas as categorias produzidas pela mãe.

$\mathrm{Na}$ filmagem, houve uma maior produção de Português pelo Edu, pois ele sabia que a mãe compreendia o que ele estava falando, mesmo a mãe somente haver sinalizado, reforçando a ideia de que, já nessa idade, Edu teria uma preferência pela língua portuguesa, demonstrando que a língua do ambiente influencia a produção individual do sujeito bilíngue (KANTO et al., 2013). Os adultos produziram as mesmas categorias entre si e, por sua vez, Edu produziu as mesmas categorias que adultos, às vezes, somente em menor quantidade.

\subsection{Produção: Edu com Lara}

Em relação a produção de Edu com Lara observou-se os seguintes aspectos:

A. $\quad$ gráfico 4 mostrou as produções oral-auditiva e visual-espacial de Edu (3;08), quando estava interagindo com Lara. Nessa idade, como mencionado antes, Edu está na fase final de aquisição da linguagem, quando, normalmente, existe a produção de sentenças (QUADROS; FINGER, 2017). Foi demonstrado também o conhecimento em Português, pois Edu produziu sentenças complexas como "MEU PAPAI ESTÁ PEGANDO O CARRO". Nessa sentença, há construção gramatical detalhada, constituída de sujeito e predicado, e também o uso de classes verbais complexas, como verbo de ligação e verbo no gerúndio. Ainda sobre a produção de sentenças, há uma dificuldade, pelo Edu, em conjugar verbos irregulares, como na frase "QUEM É O AZUL É EU", sendo que a flexão gramaticalmente correta do segundo verbo "ser" nesta frase deveria ser "sou" e não "é", fato que é normal durante o processo de desenvolvimento linguístico (QUADROS; FINGER, 2017).

B. Já a relação de Edu com a Lara na língua de sinais não ocorreu output de sentenças por Lara, já Edu continuou com a produção de sinais e apontação, como pode ser visto. Essas são características fundamentais, que demonstram que Edu está se desenvolvendo em ambas as línguas, podendo a sua produção se inserir no fenômeno de Interferência Dinâmica - explicada por Grosjean (1989) - quando uma língua, esporadicamente, é produzida com a outra por um ser bilíngue. Esses dados também vão ao encontro dos resultados de Petitto (2003), que afirmam que a produção linguística tende a diminuir ou aumentar de acordo com o interlocutor envolvido. $\mathrm{O}$ output de Edu de sinais foi todo relacionado com os assuntos discutidos durante as sessões de gravação, como "PEQUENO", "GRANDE”, "SOZINHO”, ou seja, com o meio ao qual a criança estava inserida, relação que também representa um fator esperado no desenvolvimento da aquisição: "dos três anos em diante, a criança fala sobre coisas do seu ambiente imediato, sobre o que está fazendo ou planeja fazer” (QUADROS, 2011, p. 21).

C. O MLU de Edu em PORTUGUÊS observado na tabela 3 mostrou que ele se enquadra no quarto estágio de aquisição da linguagem, de acordo com Brown (1973). O processo de aquisição 
geralmente varia, sendo completado, normalmente, aos cinco anos de idade. O MLU em PORTUGUÊS de Edu demonstra a produção normal de uma criança nessa idade, estando Edu iniciando a fase final da aquisição, que seria o quinto estágio.

\subsubsection{Sensibilidade: Edu (3;08) com Lara}

Como pode ser visto pelos dados, as observações sobre a sensibilidade de Edu em relação ao interlocutor são expostas a seguir:

A. Edu produziu maior quantidade de palavras e sentenças do que as outras categorias, assim como a Lara;

B. Assim como Lara, Edu usou o Português como língua primária na sessão de filmagem;

C. Edu produziu pouquíssimo em língua de sinais, comparado com a produção em Português;

D. Os fatores gramaticais como MLU, em relação a Edu foram maiores em Português do que em Libras. Portanto, esses resultados são mais uma forma de corroborar que aquisição da linguagem da criança sofre influência dos interlocutores interagentes nesse processo.

\subsection{Produção: Edu $(3 ; 08)$ com o pai}

Quanto a produção do Edu com o pai, foram observados os seguintes aspectos:

A. $\quad$ gráfico 5 corresponde às produções de Edu (3;08), quando estava interagindo com o pai. Nota-se que houve produção de todas as categorias de ambos participantes, no que tange à produção gesto-visual. Edu produziu sentenças negativas e também afirmativas, contendo apontação "TER NÃO HOMEM ARANHA" e "IX (figura do livro) VERDE”. Essas características sentenciais são correspondentes ao que ocorre com a produção de crianças surdas na idade de três anos, como pode ser visto a seguir:

A criança fala sobre o que ela está fazendo e pode solicitar diferentes coisas. Ela pode identificar coisas em figuras e livros e descrever pessoas e objetos por meio de suas características. Ela fala sobre onde estão as coisas, onde as pessoas estão indo e sobre quem vem a ela. Ela começa a usar frases curtas e sentenças (QUADROS, 2011, p. 21).

B. A autora discorre sobre as características da produção na aquisição da criança surda, sendo similares às da produção de Edu, pois essa produção teve relação com os objetos e pessoas, com a construção de sentenças curtas. Outra colocação de Quadros (2011) - que também traz relação à produção de Edu - é que as crianças surdas usam consistentemente pronomes e, inclusive, indicações espaciais, com referentes presentes no discurso. Nesse viés, há uma semelhança entre a aquisição de crianças surdas e a de Edu, porém em idade distinta, já que crianças surdas começam a ter este tipo de comportamento em uma idade menor, tipicamente aos três anos. Essa diferença de idade para obtenção do mesmo comportamento pode ser explicada pelo fato de que a pesquisa de Quadros (2011) ocorreu em um contexto natural de aquisição da criança com pais surdos e parentes surdos, onde, provavelmente, o input linguístico foi maior.

C. No que tange à produção oral-auditiva, foram encontradas todas as categorias estabelecidas na pesquisa. O MLU de Edu, visto na tabela 4, foi de 3,7, ou seja, a criança se enquadra no quarto estágio da aquisição da linguagem (BROWN, 1973), sendo este um número muito próximo ao último estágio da aquisição - que seria 4. Isso é marcante, pelo fato de Edu estar próximo ao final da aquisição da linguagem, que acontece por volta dos quatro ou cinco anos (KAIL, 2013) e já estar produzindo um MLU considerável. Outra averiguação é a produção de sentenças por Edu 
com algumas características como uma perfeita conjugação verbal, uso de preposição, negação e palavras complexas. Alguns exemplos de frases com estas características seriam: "EU AINDA NÃO TERMINEI”, “TENHO MEDO DE HIPOPÓTAMO”, "VOLTA PARA TU VER”.

Toda esta produção com alto grau de variabilidade e complexidade gramatical em Português são de extrema importância, uma vez que mostram que Edu está adquirindo esta língua regularmente, fato que vai ao encontro da pesquisa de Kanto et al. (2013), que dialoga que a criança bilíngue produz a língua majoritária do país, independente da língua falada pelos pais. Nesse sentido, assim como na pesquisa de Petitto (2013), é plausível afirmar que o bilinguismo não prejudica o desenvolvimento linguístico da criança em qualquer língua, mesmo se os pais produzirem somente uma delas, pois a criança, naturalmente, terá acesso à língua majoritária do país. Essas mesmas conclusões coincidem também com as da pesquisa de Chen Picheler et al. (2014), que aferiu que o desenvolvimento do inglês por Codas era equivalente ao de crianças monolíngues, ocorrendo o mesmo no desenvolvimento do Português pelo Edu, em fase de aquisição da linguagem.

\subsection{Sensibilidade: Edu com o pai}

Existiu claramente uma sensibilidade de Edu em relação ao pai, sendo destacada em várias vertentes:

A. $\quad$ Edu produziu todas as categorias gesto-visuais, assim como o pai;

B. A língua primária de Edu foi a Libras, assim como o pai, como esclarecido por Quadros (2017), a língua primária da criança pode variar, e os dados com o pais, em diversas categorias, mostram que o interlocutor interfere nesse processo;

C. Edu diminuiu a produção de Português, quando comparado a outros interlocutores e aumentou a produção de Libras.

D. A quantidade de produção nas categorias, foi similar à do pai, com exceção de sentenças, que exige um conhecimento linguístico maior;

E. Edu produziu a maior quantidade de MLU vista na pesquisa, em relação à língua de sinais

Nesse sentido, no caso da interação de Edu com o pai mostrou destaque em comparação àquelas com outros interlocutores tanto em quantidade quanto em categorias de produção linguísticas. A influência do interlocutor já havia sido demonstrada em pesquisas anteriores na área de Aquisição da Linguagem (NAVARRO, 2003; PETITTO et al., 2003; LILLO-MARTIN, 2014; CHEN PICHLER et al., 2014), porém, tentou-se nesta pesquisa demonstrar tipicamente esta influência. Um fator para tal sensibilidade ser maior com o pai, quando comparado com outros interlocutores, como a mãe, já que ambos são surdos, é que o pai sinaliza com Edu em todos os momentos de contato diário, e nunca utiliza do recurso da oralização, diferente da mãe, que eventualmente utiliza-o.

Outra constatação observada a partir dos dados analisados é que Edu consegue manter um output linguístico da língua de sinais com o pai, com o modo bilíngue, tema explorado na pesquisa de Grosjean (2001) a qual esclareceu que a língua primária de Edu passou a ser a língua de sinais com o pai. Nesse sentido, a influência linguística foi claramente identificada.

4.6 Análise da comparação das produções: Edu (3;08) com Lara e pai

Ao comparar as produções do Edu com a Lara e o pai, observou-se os seguintes pontos: 
A. Edu produziu todas as categorias com o pai em relação à produção gesto-visual, em contraste de somente algumas na interação com Lara. Isto demonstra que, mesmo o pai utilizando somente Libras para se comunicar, Edu foi capaz de produzir em ambas as línguas, demonstrando que a língua de sinais não bloqueou a sua produção em Português. É interessante notar que o output de Edu em Libras com o pai foi muito maior do que com Lara - que utiliza somente o Português para se comunicar -, mais uma vez, demonstrando a influência do interlocutor no output da criança Coda. O fato de Edu não ter produzido todas as categorias gramaticais em Libras com Lara não mostra um bloqueio da produção de Libras já que a produção dessa língua de fato ocorreu, porém em menor quantidade.

B. Já em relação à produção oral-auditiva, todas as categorias foram produzidas pelo Edu com ambos os interlocutores. É perceptível, no entanto, a maior produção de Português na interação com Lara, já que ela produzia muito mais Português do que o pai, o que, novamente, demonstra a influência do interlocutor no output linguístico de Edu.

C. Esta produção mista, corroborando com a conclusão de que Edu está, de fato, adquirindo ambas as línguas, com um output bilíngue, assim como ocorrido nas pesquisas de Chen Picler et al. (2014) com outras crianças Codas.

D. Na interação com o pai é explícito que o interlocutor está influenciando na produção da criança, devido ao fato de Edu diminuir a produção do Português e aumentar a produção de Libras, transformando-a, quantitativamente, na língua primária da seção, na interação com o pai. Esse processo corresponde com a pesquisa de Lillo-Martin et al. (2014). Semelhantemente, o inverso ocorreu com a interlocutora Lara. Sendo assim, independentemente dos interlocutores interagentes, Edu continuou produzindo ambas as línguas em diversas categorias e quantidades. Isso reforça a teoria de um modelo linguístico único, contemplado pelos autores Emmorey et al. (2008) e Lillo-Martin et al. (2013), englobando o modelo monolíngue, adicionando-lhe somente fatores de outra língua, sendo elas adquiridas ao mesmo tempo, sendo combinadas por meio da síntese das línguas (ver mais detalhes em Lillo-Martin et al. 2016).

\section{Considerações finais}

No presente trabalho, foi analisada a aquisição bilíngue bimodal de uma criança Coda, chamada ficticiamente de Edu, em duas idades distintas - 1;04 e 3;08 -, abrangendo o início e final do processo de aquisição da língua. Esta análise foi conduzida através do estudo de registros realizados em diferente sessões de vídeo, no contexto do projeto BIBIBI, demonstrando a interação desta criança com diferentes interlocutores, de diferentes contextos linguísticos, com a intenção de se compreender a relação do output linguístico de Edu com os inputs dos interlocutores nas línguas dominadas por eles. Para tal finalidade, foram analisadas as produções oral-auditivas e gestuais-visuais nestes vídeos tanto da criança, nas idades mencionadas, quanto de seus interlocutores - mãe, Lara, pai e Carlos -, sendo eles surdos ou ouvintes, monolíngues ou bilíngues, oralizados ou não oralizados. Estas análises contaram com a categorização dos elementos de ambas as produções oral-auditiva e gesto-visual, além do cálculo de MLU entre os participantes de cada interação linguística.

Como resultado, foi possível perceber a influência do interlocutor na produção da criança, em ambas modalidades linguísticas, tanto no que tange ao tipo de produção quanto à sua quantidade. Além disso, é interessante ressaltar que Edu produziu em ambas línguas - Português e Libras - independente da(s) língua(s) que o interlocutor dominava, demonstrando, deste modo, seu desenvolvimento bilíngue bimodal. 


\section{Agradecimentos}

Agradecemos à National Institute of Health $(\mathrm{NIH})$ que financiou a coleta de dados de Codas, entre eles, do EDU, sujeito desta pesquisa (NIH\#R01DC009263) e à CAPES pelo financiamento da bolsa de mestrado de Bianca Sena Gomes.

\section{Referências}

AUGUSTO, M.R.A. Teoria gerativa e aquisição da linguagem. Sitientibus, Feira de Santana, n. 13, pp. 115-120, 1995.

BROWN, R. A first language: The early stages. Harvard U. Press, 1973.

CAVALCANTI, M.C. Estudos sobre educação bilíngüe e escolarização em contextos de minorias linguísticas no Brasil. Delta, v. 15, n. especial, 1999.

CHOMSKY, N. Syntactic structures. In: CHOMSKY, N. Aspects of the theory of syntax. Cambridge, Mass.: MIT Press, 1965.

CHOMSKY, N. Linguagem e mente. 3. ed. São Paulo: Ed UNESP, 2009. Tradução de Roberto Leal Ferreira.

CHOMSKY, N. Linguistics and cognitive science: Problems and mysteries. The Chomskyan Turn, pp. 26-53, 1991.

EMMOREY, K.; BORINSTEIN, H.B.; THOMPSON, R. Bimodal bilingualism: code-blending between spoken English and American Sign Language. In: Proceedings of the 4th International Symposium on Bilingualism. Cascadilla Press Somerville, MA, 2005. pp. 663-673.

EMMOREY, K. Bimodal bilingualism. Bilingualism: Language and cognition, v. 11, n. 1, pp. 43-61, 2008.

EMMOREY, K. The source of enhanced cognitive control in bilinguals: Evidence from bimodal bilinguals. Psychological science, v. 19, n. 12, pp. 1201-1206, 2008.

GROSJEAN, F. The bilingual's language modes. In: NICOL, J. (Ed.) One mind, two languages: bilingual language processing, v. 122, 2001.

GROSJEAN, F. Life with two languages: An introduction to bilingualism. Harvard University Press, 1982.

GROSJEAN, F. Bilingual: Life and reality. Cabridge, MA: Harvard University Presss, 2010.

GROSJEAN, F. Cultural and Language Diversity and the Deaf Experience. In: PARASNIS, Ila. Living with two languages and two cultures. Cambridge: Cambridge University Press, 1996. pp. 20-37.

GROSJEAN, F. Neurolinguists, beware! The bilingual is not two monolinguals in one person. Brain and language, v. 36, n. 1, pp. 3-15, 1989.

GROSJEAN, F. The right of the deaf child to grow up bilingual. Revista da FENEIS, v. 2, n. 6, pp. 26-27, Rio de Janeiro, 2000.

KAIL, M. Aquisição da linguagem. Traduzido por Marcos Marcionilo. Editora: Parábola. São Paulo, 2013.

LILLO-MARTIN, D.; DE QUADROS, R.M.; PICHLER, D. C. The development of bimodal bilingualism. Linguistic Approaches to Bilingualism, v. 6, n. 6, pp. 719-755, 2016.

LILLO-MARTIN, D. et al. Language choice in bimodal bilingual development. Frontiers in Psychology, v. 5, pp. 154-167, 2014.

LILLO-MARTIN, D. The point of view predicate in American Sign Language. In: Language, gesture, and space. Psychology Press, 2013. pp. 165-180.

MARCELINO, M. Bilinguismo no Brasil: significado e expectativas. Revista Intercâmbio, v. XIX, pp. 1-22, 2009, São Paulo: LAEL/PUC-SP. 
OLIVEIRA, A.M.R. Acesso ao léxico e alternância de línguas em bilingues. Educação $\mathfrak{E}$ Comunicação, pp. 86-101, 2001.

QUADROS, R. M. Educação dos Surdos: Aquisição da Linguagem. Porto Alegre: Artes Médicas, 1997.

QUADROS, R. M. Lingua de Herança: Língua Brasileira de Sinais. Porto Alegre: Penso, 2017.

QUADROS, R. M. de et al. Mosaico da linguagem das crianças bilíngues bimodais: estudos experimentais. Revista Brasileira de Linguística Aplicada, v. 16, n. 1, 2016.

QUADROS, R. M.; CHRISTMANN, K.; DOMINGOS, F.K.P.; OlIVEIRA, J.S. O Software ELAN como Ferramenta para Transcrição, Organização de dados e Pesquisa em Aquisição da Língua de Sinais. In: IX Encontro do CELSUL. Anais [...]. Universidade do Sul de Santa Catarina, Palhoça, SC, out. 2010.

QUADROS, R. M.; CRUZ, C, R. Lingua de Sinais: Instrumentos de Avaliação. Porto Alegre. Artmed, 2011.

QUADROS, R. M.; CRUZ, C. R.; PIZZIO, A.L. Memória fonológica em crianças bilíngues bimodais e crianças com implante coclear. Revista virtual de estudos da linguagem, v. 10, n. 19, pp. $185,2012$.

QUADROS, R. M.; GOMES, B.; Efeito do input na produção bilíngue bimodal de uma criança coda. Revista Vídeo Registros em Libras. Florianópolis, 2013.

QUADROS, R. M.; FINGER, I.; Teoria da Aquisição da Linguagem. Florianópolis. 3. ed. Editora UFSC, 2017.

QUADROS, R. M.; LILLO-MARTIN, D.; EMMOREY, K. As línguas de bilíngues bimodais. Linguistica: Revista de Estudos Linguisticos da Universidade do Porto, v. 11, pp. 139-160, 2017.

QUADROS, R. M.; LILLO-MARTIN, D.; CHEN PICHLER, D. Early effects of bilingualism on WH-question structures: Insight from sign-speech bilingualism. Proceedings of GALA 2011, pp. 300308, 2013.

QUADROS, R. M.; LILLO-MARTIN, D.; PICHLER, D. C. O que bilíngues bimodais têm a nos dizer sobre desenvolvimento bilíngue?. Letras de hoje, v. 48, n. 3, pp. 380, 2013.

QUADROS, R. M.; LILLO-MARTIN, Diane; PICHLER, D.C. Sobreposição no desenvolvimento bilíngue bimodal. Revista Brasileira de Linguística Aplicada, v. 14, n. 4, 2014.

QUADROS, R. M.; KARNOPP, L. Lingua de Sinais Brasileira: Estudos Linguísticos. Porto Alegre: Artmed, 2004.

QUADROS, R. M.; MASSUTTI, M. CODAs brasileiros: Libras e Português em zonas de contato. Estudos surdos II. Rio de Janeiro: Arara Azul, 2007.

SKLIAR, C.; QUADROS, R. Invertendo epistemologicamente o problema da inclusão: os ouvintes no mundo dos surdos. Estilos da Clínica, v. 5, n. 9, pp. 32-51, 2000.

Recebido em: 30/09/19

Aceito em: 07/11/19 